JPAI

Jurnal Perempuan dan Anak Indonesia

Volume 3 Nomor 1, [September 2021], hal. 22-29

DOI: https://doi.org/10.35801/jpai.3.1.2021.36745

ISSN 2686-2891

\title{
PKM Pemberdayaan Perempuan di UMKM Biovina Herbal untuk Perbaikan Pengeringan Bahan Baku Herbal Standar BPOM
}

\author{
Dingse Pandiangan*1, Nelson Nainggolan ${ }^{2}$ \\ ${ }^{1}$ Jurusan Biologi FMIPA Universitas Sam Ratulangi Manado Indonesia \\ ${ }^{2}$ Jurusan Matematika FMIPA Universitas Sam Ratulangi Manado Indonesia \\ *Penulis Korespondensi. Email: dingsepan@unsrat.ac.id
}

\begin{abstract}
ABSTRAK
UMKM Biovina didirikan para perempuan dan ibu rumah tangga yang tergabung bersama untuk tujuan memproduksi tumbuhan obat tradisional yang masih dalam bentuk jamu. UMKM ini masih dalam tahap perintisan dan semua aspek pengelolaannya masih manual dan konvensional. Melalui program PKM (Program Kemitraan Masyarakat) yang dilakukan oleh LPPM Unsrat melalui program pengabdian dilakukan perbaikan pengeringan yang terkendala jika musim penghujan yang sering mengalami kerusakan yang tidak terstandar BPOM. Kegiatan atau program ini dilakukan untuk memperbaiki kualitas pengeringan bahan baku di UMKM tersebut. Adapun metode pelaksanaan yang akan pada program ini yaitu penyuluhan, pelatihan, pendampingan dan evaluasi terhadap aspek-aspek yang menyebabkan masalah UMKM tersebut. Proses perbaikan yang dilakukan adalah melalui pembangunan area pengeringan yang higienis dan alat-alat pelengkapnya dengan membangun teras rumah produksi Biovina dengan atap seng tembus sinar matahari sebagian dan yang lainnya atap seng tertutup untuk pengeringan yang tidak kena sinar matahari. Hasil evaluasi menunjukkan bahwa bahan baku obat yang bisa dikeringkan dapat meningkat sampai 5-10 Kg berat basah yang sebelumnya hanya 0,5 Kg. Luaran dari program ini meliputi produk Biovina dalam bentuk kapsul yang sudah dikemas dalam botol dan kotak dan alat pengeringan simplisia yang standar di terapkan di UMKM Biovina. Target dan luaran kegiatan PKM ini adalah memberikan motivasi dan inovasi yang baru kepada masyarakat terutama kepadai ibuibu rumah tangga yang tergabung dalam UMKM Biovina Sea Mitra untuk memperbaiki proses pengeringan bahan baku sebelum digunakan atau dioleh jadi produk Biovina.
\end{abstract}

Kata Kunci: Tumbuhan; Obat; UMKM; Biovina; PKM; Sea Mitra.

\section{ABSTRACT}

SMEs Biovina was founded by women and housewives who joined together for the purpose of producing traditional medicinal plants which are still in the form of herbal medicine. These SMEs are still in the pioneering stage and all aspects of their management are still manual and conventional. Through the SMEs program (Community Partnership Program) carried out by LPPM Unsrat through a service program, repairs to drying are carried out which are constrained if the rainy season often experiences damage that is not standardized by BPOM. This activity or program is carried out to improve the quality of drying of raw materials in these SMEs. The implementation methods that will be in this program are counseling, training, mentoring and evaluation of the aspects that cause the SMEs problems. The repair process carried out is through the construction of a hygienic drying area and its complementary equipment by constructing a terrace of a Biovina production house with a zinc roof that is partially translucent to sunlight and the other with a closed zinc roof for drying that does not get sunlight. The evaluation results show that the raw materials for drying drugs can increase up to 5-10 Kg

Pandiangan D. dan Nainggolan N. 2021. PKM Pemberdayaan Perempuan Di UMKM Biovina Herbal..... 
wet weight which was previously only $0.5 \mathrm{Kg}$ The output of this program includes Biovina products in capsule form that have been packaged in bottles and boxes and standard simplicia drying equipment in Indonesia. apply in Biovina SMEs. The target and output of this SMEs activity is to provide new motivation and innovation to the community, especially to housewives who are members of the Biovina Sea Mitra SMEs to improve the drying process of raw materials before they are used or processed into Biovina products.

Keywords: Medicinal; Plants; Biovina; PKM; Sea Mitra

\section{PENDAHULUAN}

\section{Analisis Situasi}

UMKM Biovina Herbal berusaha memproduksi suplemen dan produk teh herbal lainnya yang dapat meningkatkan imun dengan mengadopsi hasil penelitian dari para inventor Biovina Herbal. Salah satunya adalah Biovina Mix Antidegeneratif adalah produk hasil kajian teknologi tumbuhan obat tradisional yang sudah diketahui manfaatnya sebagai antioksidan, antikanker, antikolesterol dan antidiabetes yang digolongkan dalam antidegeneratif (Pandiangan et al., 2019). Produk ini merupakan teknologi produksi obat berbahan baku herbal atau tumbuhan obat tradisional yang sudah sering dimanfaatkan masyarakat secara umum atau secara tradisi di Suku Minahasa maupun di Suku Sanger. Produk farmasi dan kesehatan ini merupakan produk baru yang belum pernah ada karena berbasis tumbuhan obat tradisional daerah.

UMKM Biovina Herbal adalah yang bergerak di bidang perdagangan barang dan jasa terutama produk minuman dan makanan fungsional terhadap kesehatan berbasis tumbuhan obat tradisional. UMKM Biovina Herbal 2019 merupakan hasil kesepakatan kaum wanita yang terkumpul dalam pelayanan Wanita (Pelwap) GPdI Khristos yang tidak bekerja (dirumah saja) diberdayakan melalui Chatering Biovina yang melayani pesanan makanan berbasis tumbuhan dan ikan yang mendukung kesehatan untuk mengurangi penyakit degenerative (kanker, jantung, hipertensi, diabetes, almeizer dan sebagainya). Visi dari usaha ini adalah Menjadi Usaha Mikro Kecil penyedia produk minuman atau makanan herbal yang berfungsi untuk peningkatan imunitas dan penurunan degeneratif dalam berbagai bentuk untuk memudahkan pengobatan tradisional membantu masyarakat ekonomi lemah di Indonesia. Misinya adalah mempopulerkan penggunaan produk berbasis natural di masyarakat Indonesia., menciptakan produk herbal untuk kesehatan berkualitas sesuai dengan perkembangan teknologi dan trend, selalu memberikan pelayanan maksimal; cepat, berkualitas, dan bertanggungjawab. Masalah yang dihadapi saat produksi Biovina adalah belum ada izin produksi dan izin edarnya, baru terdaftar secara online melalui perindustrian. Melalui PKM ini diharapkan permasalahan tersebut dapat diselesaikan dan memproduksi semua produk yang sudah diteliti manfaatnya. Permasalah atau kekurangan lainnya bahwa kemasan produk masih kurang menarik dan perlu pengembangan produk melalui kegiatan PKM ini. Demikian juga bahan baku tumbuhan obat herbalnya, pengeringannya ketika musim penghujan dan packingnya yang masih manual atau belum menggunakan alat. Berharap melalui kegiatan PKM ini akan dihasilkan produk yang lebih baik sehingga bisa bersaing dipasaran. Cara pengeringan yang dilakukan oleh Biovina Herbal adalah cara mengeringkan tumbuhan obat tradisonal yang digunakan secara 
manual dengan sinar matahari. Bersama pengusul mewawancarai pekerja pengeringan simplisia. Banyaknya sampel yang akan dikeringkan setelah dipanen perlu teknologi untuk ditawarkan membantu, bersama pengusul menawarkan kerjasama untuk membantu cara pengeringan tanpa tergantung cuaca, Sebagian menghitam karena kurangnya sinar matahari membuat simplisia sempat mengalami kerusakan.

\section{Solusi dan Target Luaran}

Dari beberapa permasalahan di atas maka yang menjadi prioritas adalah masalah aspek mutu produksi (perbaikan pengeringannya). Solusi untuk mengatasi permasalahan pengeringan bahan bakunya perlu perbaikan mutu terutama memperbaiki teknik pengeringannya yang diberikan oleh tim pengusul setelah dibuatkan oleh tim pengusul.

\section{Tujuan dan Manfaat Kegiatan}

Memberikan motivasi dan inovasi yang baru kepada UMKM Biovina untuk memperbaiki teknik pengeringannya dari cara manual konvensional dalam tampi menjadi tertata dalam satu tempat yang sudah didiberikan formasi bangunan yang sehat dan higienis untuk digunakan sebagai bahan baku obat herbal.

\section{METODE PELAKSANAAN}

\section{Sasaran Kegiatan Pengabdian}

Mitra pada kegiatan ini adalah seluruh anggota dan pengurus UMKM Biovina Herbal Sea Mitra (Gambar 1).

\section{Lokasi Kegiatan Pengabdian}

Kegiatan dilaksanakan secara daring (online) di masa Pandemi Covid 19 ini melalui aplikasi Google meet untuk segala kegiatan sosialisasi dan penyuluhan serta koordinasi dengan BPOM. Khusus praktek dan pembuatan areal pengeringan bahan baku tumbuhan obat dan produk herbal dilakukan di Desa Sea Mitra Jaga II di UMKM Biovina Herbal (Gambar 1).

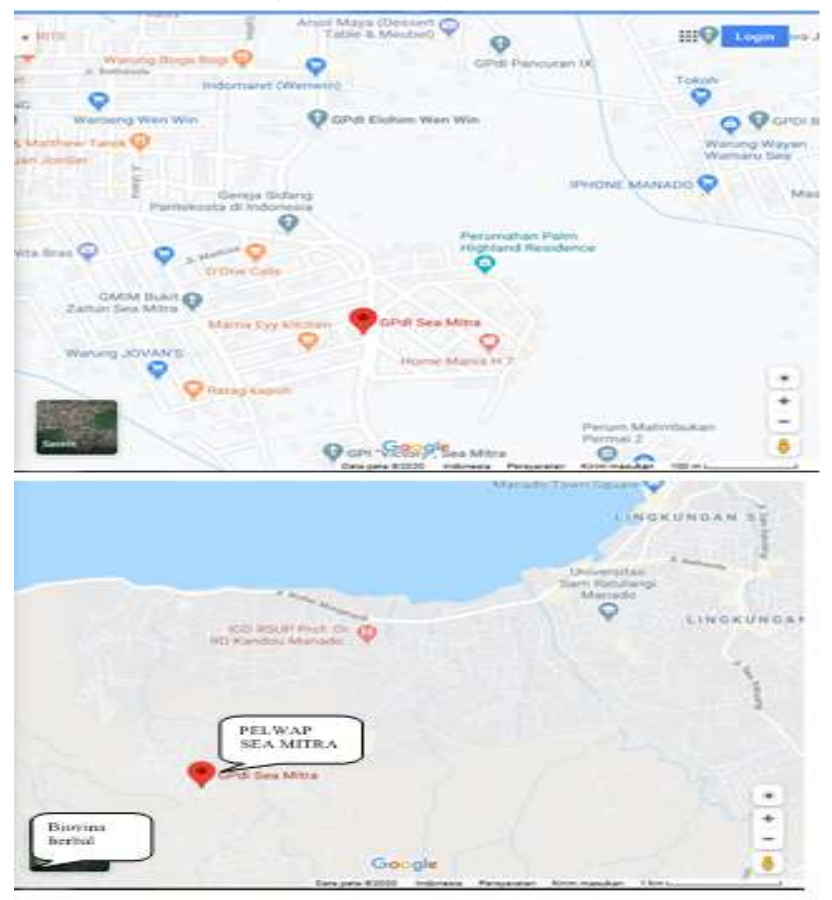

Gambar 1. Lokasi UMKM Biovina di Jaga II

Desa Sea Mitra Pineleng Minahasa

Sebelum kegiatan terlaksana, wawancara antara pengusul dan pekerja teknis lapangan diwawancarai mengenai pengeringan simplisia di UMKM Biovina. Cara pengeringan mereka adalah dengan cara mengeringkan tumbuhan obat tradisonal yang digunakan secara manual dengan di bawah sinar sinar matahari langsung dengan jumlah sampel hanya sedikit. Pengeringan dimusim hujan sering terkendala karena terlambat diangkat atau dipindahkan ke tempat yang tidak kena hujan. Banyaknya sampel yang akan dikeringkan setelah dipanen perlu teknologi untuk ditawarkan membantu melalui kerjasama untuk membantu cara pengeringan tanpa tergantung cuaca, Sebagian menghitam karena kuranya sinar 
JPAI

Jurnal Perempuan dan Anak Indonesia

matahari membuat simplisia sempat mengalami kerusakan.

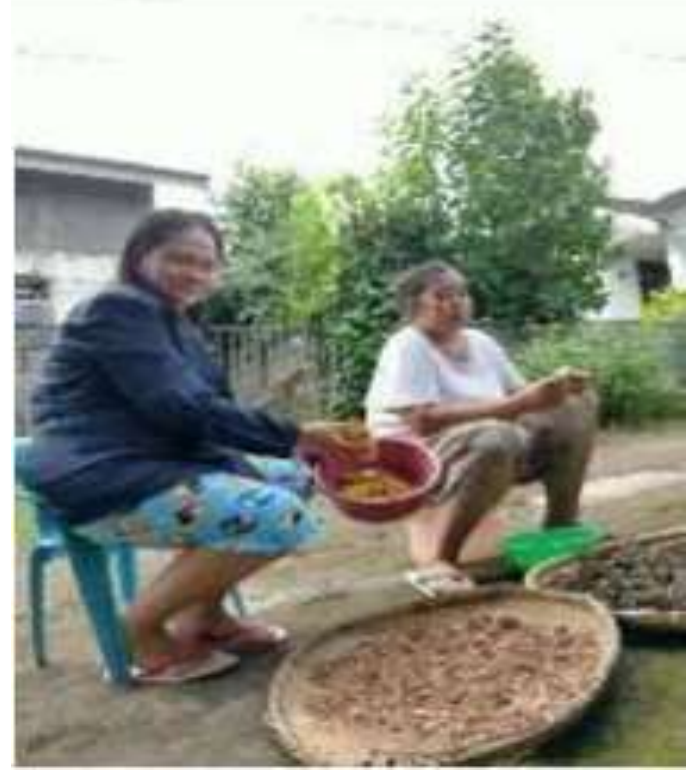

Gambar 2. Bersama pengusul mewawancarai pekerja pengeringan simplisia di daerah lokasi UMKM Biovina dan cara mengeringkan tumbuhan obat tradisonal yang digunakan secara manual dengan sinar matahari.

\section{Metode yang Digunakan}

Metode pelaksanaan kegiatan ini adalah:

\section{Memberikan Penyuluhan Kepada Mitra}

Memberikan penyuluhan kepada mitra dengan topik bahasan antara lain tentang bahan baku terstandar menurut BPOM dan aturan produksinya. Juga diperkenalkan beberapa Tumbuhan obat tradisional yang sudah dibukukan "Etnobotani Tumbuhan obat Suku Sanger" sebagai rujukan yang terdapat sekitar 118 jenis tumbuhan obat disertai pemanfaatannya.

\section{Melakukan Pembangunan Fasilitas} Pengeringan

Pembangunan fasilitas pengeringan di depan rumah usaha mereka dengan membangun seperti yang telah direncanakan pada Gambar 3 berikut ini.

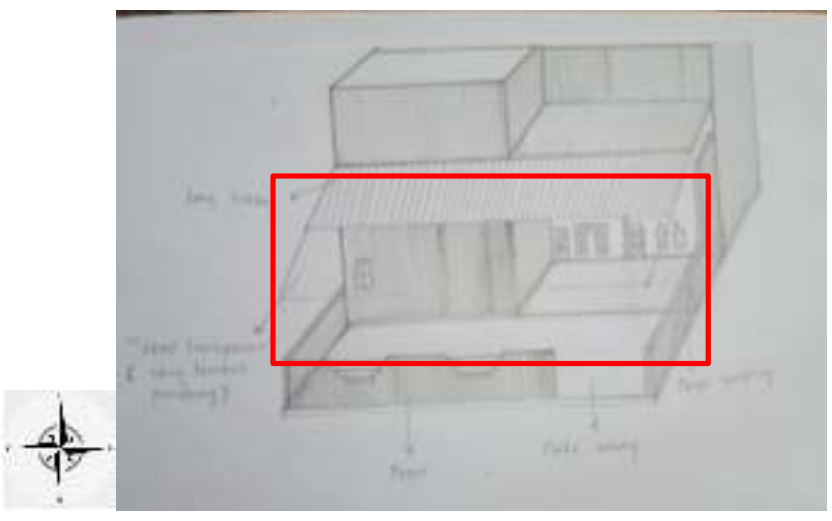

Gambar 3. Rancangan bangunan fasilitas pengeringan bahan baku tumbuhan obat tradisional untuk digunakan pada UMKM Biovina herbal yang praktis dan higienis.

\section{Pembangunan Lokasi Pengeringan}

Sebagai percontohan pengeringan di bangungan yang higienis dan praktis dengan memberikan bangunan teras rumah produksi sebagai tempat pengeringan yang terdiri dari 2 jenis atap. Satu bagian atap seng transparan (tembus sinar matahari) untuk pengeringan yang langsung dibawah sinar matahari dan sebagian lagi dengan atap seng gelap untuk mengatasi bahan baku yang harus teduh pengeringannya (matahari tidak langsung). Kemudian lantai dan dinding pagar diberikan keramik yang bisa dibersihkan dan tidak timbul jamur sehingga tetap higienis.

\section{HASIL DAN PEMBAHASAN}

\section{Pengenalan Program Melalui Rapat Koordinasi di Biovina}

Sebelum kegiatan dilakukan sosialisasi kegiatan kepada petugas dan pelaksanan di UMKM Biovina dan masyarakat sekitar CV. 
JPAI

Jurnal Perempuan dan Anak Indonesia

Volume 3 Nomor 1, [September 2021], hal. 22-29

DOI: https://doi.org/10.35801/jpai.3.1.2021.36745

Biovina secara daring (via zoom). Dilakukan pencerahan tujuan kegiatan dan rencana selanjutnya untuk mendampingi UMKM Biovina sampai bisa berproduksi.

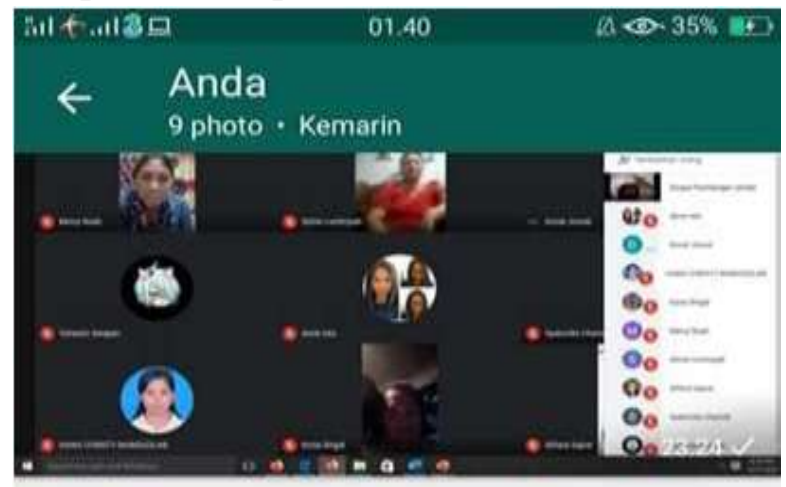

Gambar 2. Kegiatan Sosialisasi program PKM kepada petugas UMKM Biovina dan masyarakat sekitarnya.

Pemateri atau pelaksanan memberikan pencerahan dan pengarahan tentang pengobatan tradisional dengan tumbuhan obat. Materi yang diberikan secara sistematis sampai pada penemuanpenemuan hasil uji klinis obat-obatan herbal yang telah diproduksi oleh Biovana Herbal yang sudah dapat dimanfaatkan tanpa rasa ragu.

\section{Pembangunan Tempat Pengeringan Bahan Baku Obat Biovina}

Lokasi alat pengeringan bahan baku tumbuhan obat Biovina yang diinformasi dengan bahan yang tahan lama dan higenis, serta bisa mengeringkan dengan jumlah yang besar. Atap pengering ini terbuat dari seng yang transparan (tembus sinar matahari) (Gambar 3a.). Atap transparan ini lebih menguntungkan dari yang sebelumnya tanpa atap yang terkena sinar matahari secara langsung, sehingga jika hujan tiba-tiba bahan baku gampang membusuk. Melalui program ini, hal itu bisa di atasi. Meskipun hujan bahan baku tidak perlu diangkat, sebab sudah terlindungi oleh atap transparan ini. Di samping atap yang transparan, ada atap yang tidak transparan (tidak tembus matahari) (Gambar 3b.). Atap ini berfungsi untuk mengeringkan bahan baku yang tidak boleh terkena sinar matahari secara langsung. Sehingga, khasiat dari bahan baku terjaga dan tidak rusak. Rangka pengering ini terbuat dari baja ringan (Gambar 3c.), sehingga pengering lebih kokoh dan awet (tahan lama). Lantai pengering ini adalah tehel (keramik) sehingga menjadi lebih higenis dan sehat dari sebelumnya yang licin dan berlumut (Gambar 3d.). Bahan baku obat yang akan dikeringkan bisa dalam jumlah yang besar dari sebelumnya.

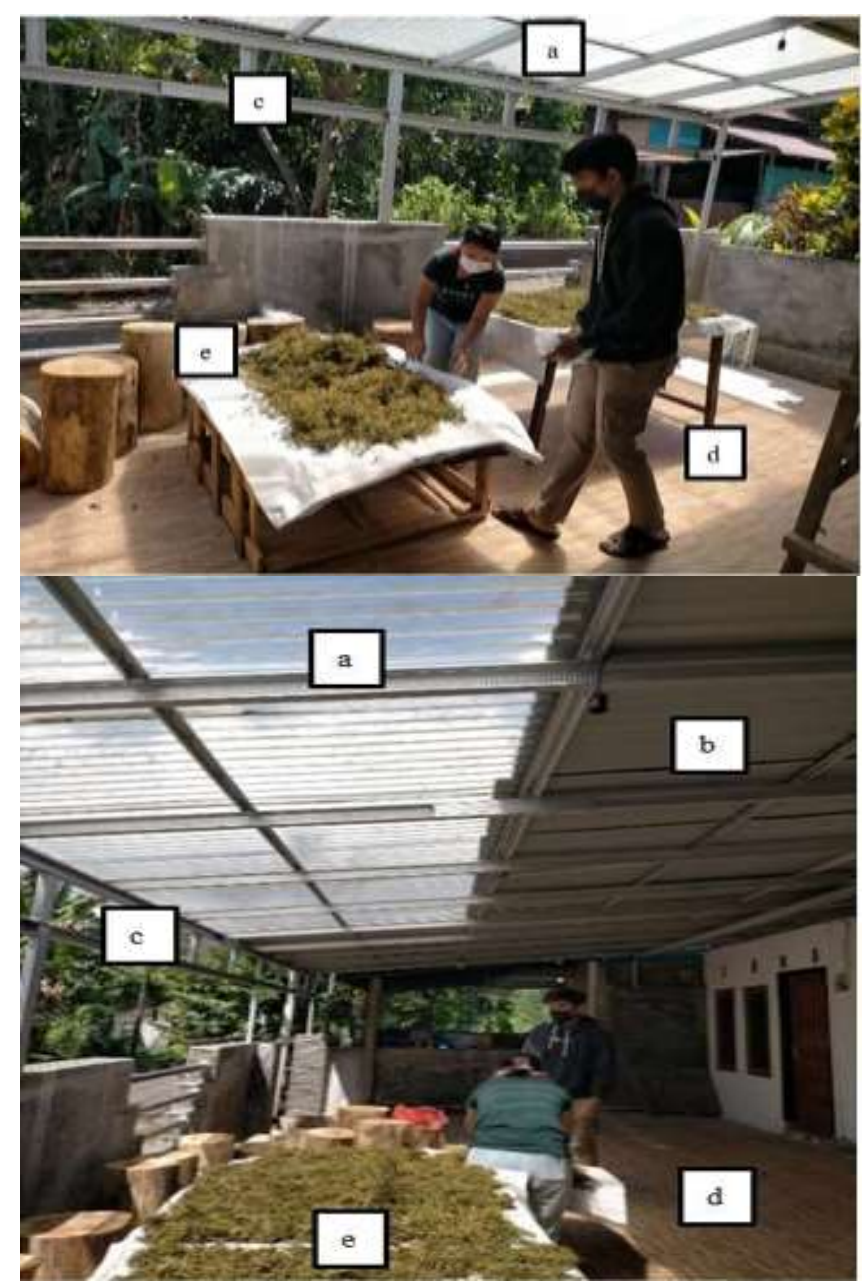

Gambar 3. Lokasi alat pengeringan bahan baku tumbuhan obat Biovina. a. Atap yang transparan (tembus sinar matahari). b. Atap tidak transparan (tidak tembus matahari). c. Rangka bangunan yang terbuat dari baja ringan. d. Lantai tehel (keramik) yang 
JPAI

Jurnal Perempuan dan Anak Indonesia

Volume 3 Nomor 1, [September 2021], hal. 22-29

DOI: https://doi.org/10.35801/jpai.3.1.2021.36745

higenis. .e. Bahan baku obat yang sedang dikeringkan dalam jumlah yang besar

\section{Penerapan Pemanfaatan Pengeringan}

Bahan baku diambil dari kebun Biovina dan dipanen bersama-sama dan dilakukan peneringan dilokasi yang sudah disiapkan dan dibangun (Gambar 3). Bangunan ini sangat khas dengan membuat areal yang bersih di tehel, diberi atap yang tembus pandang dan sinar matahari banyak tetapi ketika hujan datang mereka tidak perlu tergesa-gesa mengumpulkannya sebab sudah terlindungi dengan atap yang tembus pandang (Gambar 4A). Pengeringan Pasote, Gedi dan Porang bisa cepat dan bahan baku jadi baik dan berkualitas dan jumlah lebih banyak (Gambar 5).
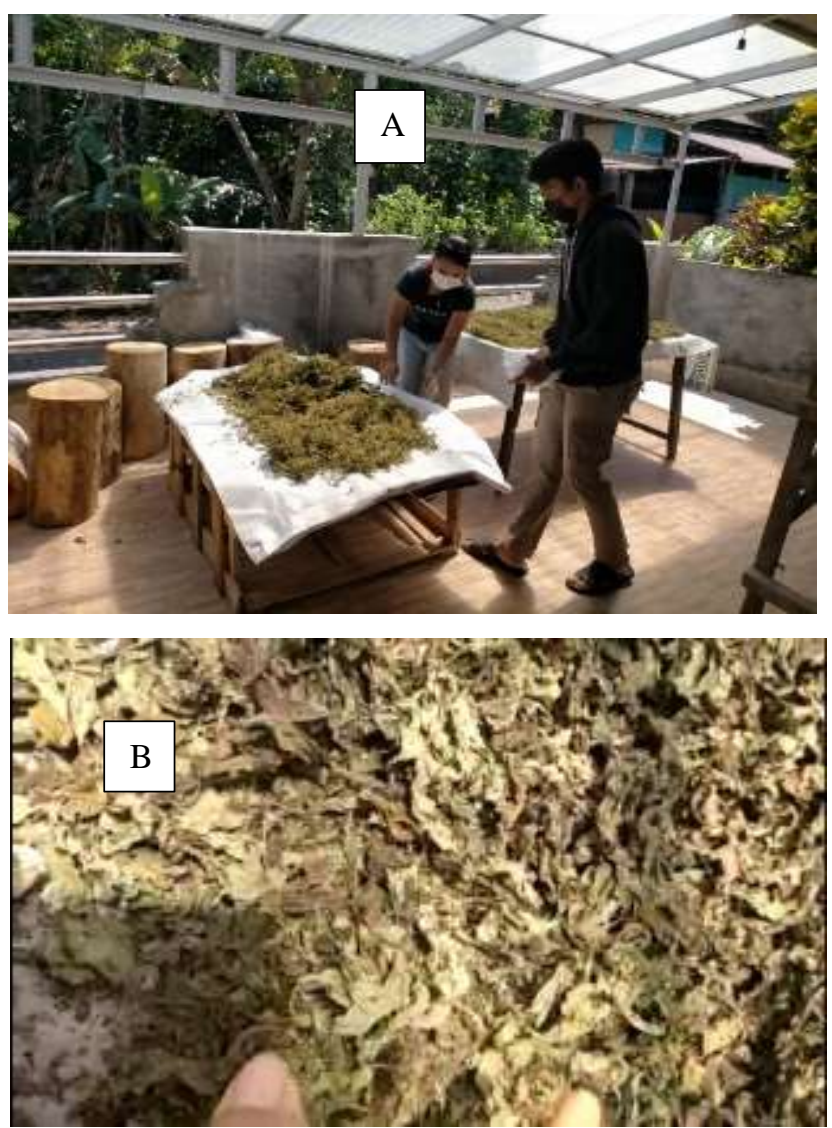

Gambar 4. Bangunan yang telah selesai dan digunakan untuk pengeringan pasote dalam jumlah besar seluas $10 \mathrm{~m} \times 3$ meter (A) dan pengeringan Biovina ada lebih banyak hasil pengeringan daun gedi sampai $10 \mathrm{Kg}$ bb (B)

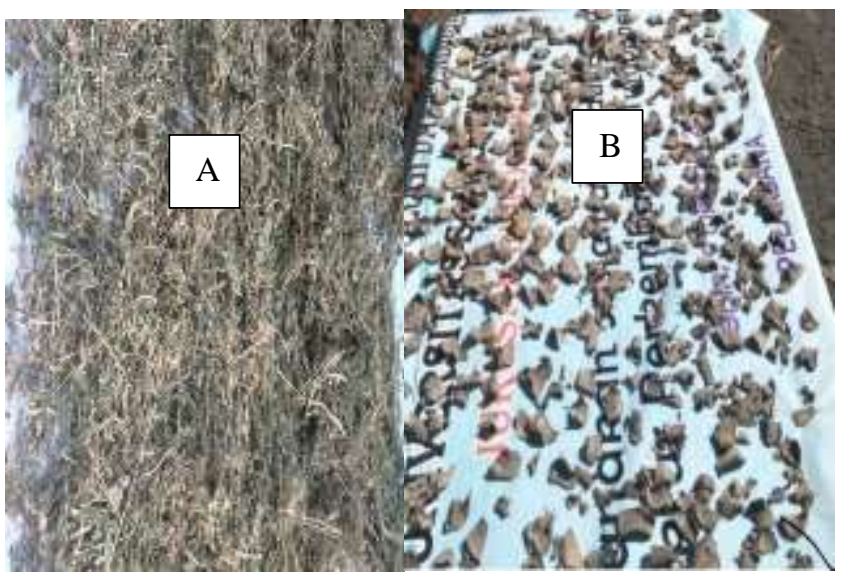

Gambar 5. Penerapan teknologi pengeringan yang terstandar dan higienis di UKM Biovina Ketika percobaan penerapannya pada pengeringan Pasote (Disphania ambrosioides) (A) dan Porang (B)

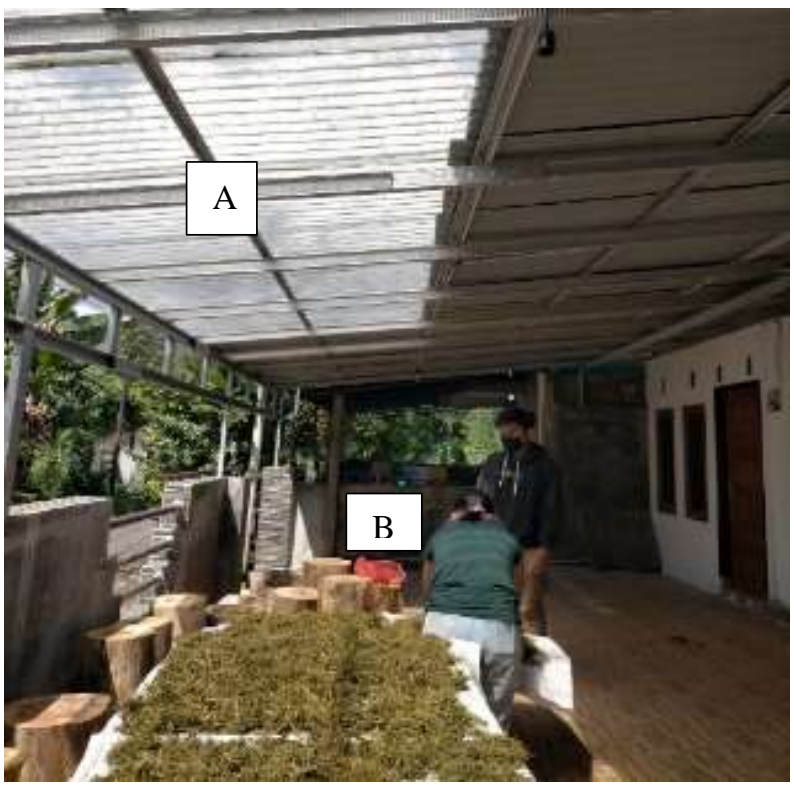

Gambar 6. Bangunan teras rumah produksi Biovina yang diberikan tempat pengeringan yang beratapkan seng transparan dan rangka baja (A) sedang memberikan percontohan kepada pengerja UKM Biovina. (B)

Ruangan pengeringan dibagi dua atap untuk pengeringan tidak lanmgsung matahari dan 
pengeringan langsung di bawah matahari. pengeringan di atas rak pengeringan dan bisa mengeringkan dalam jumlah besar. Pelaksanaan kegiatan PKM pengeringan bahan baku obat di UMKM Biovina Herbal juga telah memanfaatkan oleh 2 kelompok mahasiswa PKM RE yang lolos mendapatkan pendanaan nasional dari Belmawa Kemendikbud Ristek tahun 2021.

\section{Monitoring dan Evaluasi Kegiatan}

Hasil penerapan terus dipantau sampai dua bulan berjalan dan dilakukan tanya jawab mengenai mengenai manfaat yang dirasakan oleh UMKM Biovina yang mayoritas merupakan peserta perempuan. Perbandingan hasil pengeringan setelah penerapan pengeringan dari PKM Unsrat di UMKM Biovina dapat mengeringkan 5-10 $\mathrm{Kg}$ berat basah bahan baku tumbuhan obat (Gambar 4B, 5A, 6B, 7A) dan cara pengeringan mereka sebelumnya di atas wadah nampan yang hanya bisa mengeringkan sekitar 0,5 $\mathrm{Kg}$ berat basah (Gambar 7B)

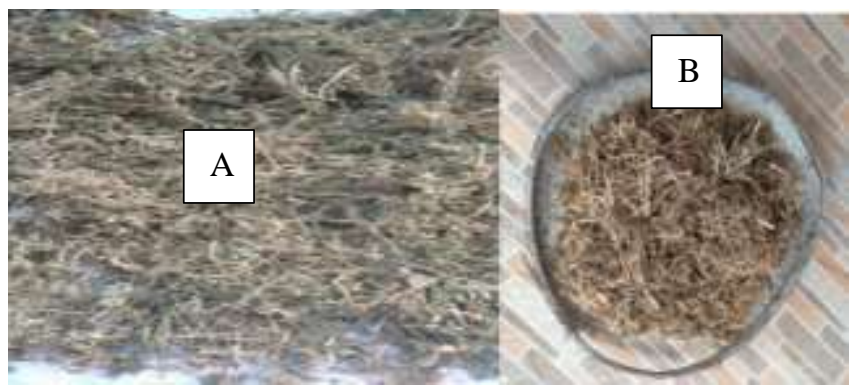

Gambar 7. Perbandingan hasil pengeringan secara penerapan teknologi dari PKM Unsrat di UKM Biovina yang dapat mengeringkan 5$10 \mathrm{Kg}$ berat basah bahan baku (A) dan cara pengeringan mereka sebelumnya diatas wadah nampan yang hanya bisa mengeringkan sekitar 0,5 Kg berat basah (B).

\section{KESIMPULAN}

Proses perbaikan yang dilakukan melalui pembangunan area pengeringan yang higienis dan alat-alat pelengkapnya dengan membangun teras rumah produksi Biovina dengan sebagian atap seng tembus sinar matahari, sebagian dan bagian yang lainnya atap seng tertutup untuk pengeringan yang tidak kena sinar matahari. Hasil evaluasi menunjukkan bahwa bahan baku obat yang bisa dikeringkan dapat meningkat sampai 5-10 Kg berat basah yang sebelumnya hanya $0,5 \mathrm{Kg}$ luaran dari program ini meliputi produk Biovina dalam bentuk kapsul yang sudah dikemas dalam botol dan kotak dan alat pengeringan simplisia yang standar di terapkan di UMKM Biovina. Target dan luaran kegiatan PKM ini adalah memberikan motivasi dan inovasi yang baru kepada masyarakat terutama kepada ibu-ibu rumah tangga yang tergabung dalam UMKM Biovina Sea Mitra untuk mmemperbaiki proses pengeringan bahan baku sebelum digunakan atau diolah jadi produk Biovina.

\section{UCAPAN TERIMAKASIH}

Ucapan terimakasih disampaikan kepada Rektor Universitas Sam Ratulangi dan Ketua LPPM Unsrat atas penugaskan pelaksanaan kegiatan ini dengan nomor surat 1761/UN12.13/PM/2021 tanggal 4 Mei 2021. Terimakasih juga atas dukungan dana PKM ini diambil dari DIPA tanggal 1 April 2021 DIPA BLU Universitas Sam Ratulangi, dengan kontrak penelitian no Nomor: 587/UN12.13/PM/2021 pada tanggal 3 Mei 2021 atas bantuan dan dukungannya agar kegiatan ini dapat terlaksana dan memberikan dampak bagi masyarakat. 
JPAI

Jurnal Perempuan dan Anak Indonesia

Volume 3 Nomor 1, [September 2021], hal. 22-29

DOI: https://doi.org/10.35801/jpai.3.1.2021.36745

\section{DAFTAR PUSTAKA}

Pandiangan D, Esyanti RR, de Queljoe E. 2008. Aktivitas Antikanker Katarantin pada sel mouse mammary cancer MmT06054. Jurnal lmiah Sains 8 (1) pp.107-113.

Pandiangan D, Nainggolan N, Kandou F, de Queljoe E. 2018b. Effectiveness of Sambote Extract on Decreasing Blood Glucose Levels of Male White Rats (Rattus norvegicus) Induced with Sucrose. International Journal of Science and Research (IJSR) 7 (11): pp. 1683-1688.

Pandiangan D, Esyanti RR, de Queljoe E. 2008. Aktivitas Antikanker Katarantin pada sel mouse mammary cancer MmT06054. Jurnal lmiah Sains 8 (1) pp.107-113.

Pandiangan D, Nainggolan N, Kandou F, de Queljoe E. 2018b. Effectiveness of Sambote Extract on Decreasing Blood Glucose Levels of Male White Rats (Rattus norvegicus) Induced with Sucrose. International Journal of Science and Research (IJSR) 7 (11): pp. 1683-1688.

Pandiangan D, Lamlean, $\mathrm{P}$, Nainggolan N, Mailangkay H, 2020Antioxidant and Anticancer Activity Tests of "Pasote" Leaf Water Extracts (Dysphania ambrosioides L.) by In Vitro Method in Leukemia Cancer Cells. The $5^{\text {th }}$ International Conference on Basic Sciences IOP Conf. Series: Journal of Physics: Conf. Series 1463 IOP Publishing. DOI:10.1088/1742-6596/1463/1/012020

Pandiangan D, Nainggolan N, Mailangkay H, Tumbol M. 2018a. The Potential Use of Catharanthus roseus as a Beach Tourism Jewelry and as an Herbal Medicine for Tourists. The 3rd International Conference on Operations Research, Sam Ratulangi
University, Manado, Indonesia, 20-21 September 2018 pp.74-84.

Pandiangan D, Nainggolan N, Mailangkay H, Tumbol M. 2020. Potential of Anticholesterol Degeneratif Drugs of Leaf Extract (Catharanthus roseus L.G. Don) on Wistar Rat (Rattus norvegicus). Sys Rev.Pharm. Volume 11 no 1: 618-625

Pandiangan D, Silalahi M, Dapas F, and Kandow F. 2019. Diversity of medicinal plants and their uses by the Sanger tribe of Sangihe Islands, North Sulawesi, Indonesia. Biodiversitas 20 (2): 621-631.

Silalahi M, Nisyawati, Walujo EB, Supriatna J. 2015b. Local knowledge of medicinal plants in sub-ethnic Batak Simalungun of North Sumatra, Indonesia, Biodiversitas 16 (1): 44-54. 